Volume 10 Issue 3, July-September 2016: pp. 413-586. Copyright (c) 2015-2016 FIAT JUSTISIA. Faculty of Law, Lampung University, Bandarlampung, Lampung, Indonesia. ISSN: 1978-5186 | e-ISSN: 2477-6238.

Open Access: http://jurnal.fh.unila.ac.id/index.php/fiat

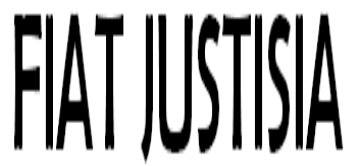

Fiat Justisia is licensed under a Creative Commons Attribution 4.0 International License, which permits unrestricted use, distribution, and reproduction in any medium, provided the original work is properly cited.

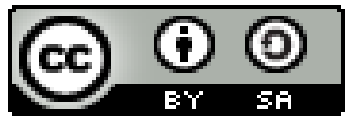

\title{
EFISIENSI PEMILIHAN ALTERNATIF PENYELESAIAN SENGKETA DALAM PENYELESAIAN SENGKETA WARALABA
}

\section{The Efficiency of Choosing Alternative Dispute Resolution to Solve a Franchise Dispute}

\author{
Rahmi Yuniarti \\ Fakultas Hukum, Universitas Lampung \\ email: rahmiyuniartizr@gmail.com
}

\begin{abstract}
Franchise as a business contract between franchisor and frachisee which in the practice sometimes leads to a dispute. A dispute happens because their rights and obligations are not met. Dispute settlement businesses can choose a judiciary or non-judiciary institution. However, considering of the business continuity, the dispute must be resolved so each side can fulfill their needs to solve the dispute. The problems in this study are the factors that can arise disputes franchise and the efficiency of selecting alternatives of dispute resolution to resolve the dispute franchise. This type of the research used by the researcher is a normative legal research. This type of research is a descriptive research. The conclusions of this study are the factors that cause disputes franchise is the existence of rights and obligations are not met and fulfilled, and it happens mostly because the oversight and discontinuance of the franchise that are assumed not giving advantages or inflicting one of the parties. Moreover, there are possibilities of not keeping promises which have been decided before.
\end{abstract}

Keywords: Alternative Dispute Resolution, Franchise Dispute

\begin{abstract}
Abstrak
Waralaba sebagai suatu kontrak bisnis antara franchisor dan frachisee dalam pelaksanaannya tidak sedikit yang menimbulkan suatu sengketa. Suatu sengketa muncul dikarenakan adanya hak dan kewajiban yang tidak terpenuhi. Penyelesaian sengketa bisnis dapat memilih lembaga pengadilan
\end{abstract}


atau lemabaga non-peradilan. Namun, dengan pertimbangan akan kelanjutan bisnis yang dijalani alternatif penyelesaian sengketa dianggap lebih dapat menyalurkan keinginan para pihak untuk menyelesaiakan sengketa bisnis. Permasalahan pada penelitian ini adalah faktor-faktor yang dapat menimbulkan sengketa waralaba dan efisiensi pemilihan alternatif penyelesaian sengketa untuk menyelesaikan sengketa waralaba. Jenis penelitian yang digunakan penulis dalam penelitian ini adalah bersifat penelitian hukum normatif. Tipe penelitian ini adalah penelitian deskriptif. Simpulan dari penelitian ini, faktor-faktor yang menyebabkan timbulnya sengketa waralaba adalah adanya suatu hak dan kewajiban yang tidak terpenuhi dan paling banyak terjadi dikarenakan pengawasan dan pemutusan hubungan waralaba yang dianggap merugikan salah satu pihak. Selain itu, ketidakpastian karena ada kemungkinan tidak ditepatinya janji serta risiko permintaan yang tidak sesuai dengan yang direncanakan.

\section{Kata Kunci: Penyelesaian Sengketa, Sengketa Waralaba}

\section{A. Pendahuluan}

Salah satu cara bagi masyarakat untuk memperoleh kesejahteraan ekonomi adalah dengan berwirausaha. Seringkali seseorang berhasrat untuk mendirikan usaha baru karena didorong adanya peluang yang menurut mereka dapat dimanfaatkan untuk berwirausaha. Namun, biasanya si calon wirausahawan memiliki keresahan akan kegagalan terhadap bisnis yang mereka jalani. Keresahan tersebut timbul dikarenakan kurangnya pengalaman dalam berbisnis. Membuka usaha atau berusaha adalah sesuatu yang sangat berisiko dan penuh ketidakpastian. Namun, di balik itu ada potensi yang menjanjikan pada suatu peluang bisnis tertentu. Masing-masing pilihan tentunya memiliki kelebihan dan kekurangan. Salah satu diantaranya peluang usaha yang banyak diminati adalah Bisnis waralaba (franchise) yang telah menjadi suatu usaha yang berkembang saat ini. Franchise berasal dari bahasa Prancis yaitu franch (bebas), fancher (membebaskan, memberikan hak istimewa), dan dalam bahasa Indonesia Franchise adalah waralaba. Waralaba itu sendiri adalah berasal dari kata wara yang artinya lebih dan laba yang artinya untung. Jadi Franchise/waralaba dalam bahasa Indonesia adalah usaha yang memberikan keuntungan lebih atau istimewa.

Menurut Pasal 1 angka 1 Peraturan Pemerintah No 42 Tahun 2007 tentang waralaba sebagaimana yang didukung dengan aturan pelaksana Peraturan Menteri Perdagangan No 3/M-DAG/PER/8/2008 tentang penyelengggaraan waralaba menyatakan bahwa yang dimaksud dengan waralaba adalah hak khusus yang dimiliki oleh orang perseorangan atau badan usaha terhadap system bisnis dengan ciri khas usaha dalam rangka memasarkan barang dan/atau jasa yang telah terbukti berhasil dan dapat 
dimanfaatkan dan/atau digunakan oleh pihak lain berdasarkan perjanjian waralaba. ${ }^{1}$

Di Indonesia, sistem bisnis penjualan secara waralaba sangat diminati oleh pembisnis waralaba asing dimana mereka memberikan izin kepada pengusaha lokal untuk mengelola waralaba asing tersebut dan tentunya akan berakibat menimbulkan saingan yang berat bagi pengusaha kecil lokal yang bergerak di bidang usaha sejenis.

Menurut Douglas J Queen, konsep bisnis waralaba yang sudah teruji kemungkinan besar mengimbangi biaya awal dan royalti selanjutnya dari waralaba tersebut. Besarnya biaya tersebut memberikan hak pada pemilik waralaba berupa penyediaan pelayanan utama berikut ini ${ }^{2}$ :

1. Pemilihan dan pengkajian lokasi,

2. Spesifikasi peralatan dan tempat,

3. Pelatihan manajemen dan staf,

4. Dukungan promosi dan iklan,

5. Manfaat pembelian dan volume, dan

6. Merek dagang yang terkenal.

Berdasarkan penyediaan pelayanan tersebut oleh pemilik waralaba, maka pembeli waralaba mempertimbangkan kemungkinan memperoleh keuntungan bila membeli/menerima izin perolehan waralaba.

Sebagai suatu kontrak bisnis, maka perjanjian waralaba merupakan perjanjian secara tertulis antara Pemberi Waralaba dengan Penerima waralaba. Sebagaimana bisnis pada umumnya, kewajiban-kewajiban dalam suatu kontrak waralaba berpotensi dan terkadang dilanggar. Timbulnya sengketa dalam bisnis waralaba terjadi bila salah satu pihak melanggar isi perjanjian. Jika salah satu pihak melanggar isi perjanjian, maka pihak yang lain dapat menuntut pihak yang melanggar tersebut sesuai dengan hukum yang berlaku. Dua area yang biasanya dicakup dalam perjanjian franchise yang paling banyak menimbulkan masalah hukum yang potensial, yaitu pengawasan mutu dan pemutusan perjanjian franchise. ${ }^{3}$

Penyelesaian sengketa dapat dilakukan melalui dua proses. Proses penyelesaian sengketa tertua melalui proses litigasi di dalam pengadilan kemudian berkembang proses penyelesaian sengketa melalui kerjasama (kooperatif) di luar pengadilan. Proses litigasi menghasilkan kesepakatan yang bersifat adversarial yang belum mampu merangkul kepentingan bersama, cenderung menimbulkan masalah baru, dan menimbulkan permusuhan di antara pihak yang bersengketa. Sebaliknya, melalui proses di

\footnotetext{
${ }^{1}$ Lihat Peraturan Pemerintah Nomor 42 Tahun 2007 tentang Waralaba.

${ }^{2}$ Muhammad, Abdulkadir. (2010). Hukum Perusahaan Indonesia. Bandung: Citra Aditya Bakti, p. 337.

${ }^{3}$ Muhammad, Abdulkadir. Op. Cit., p. 566.
} 
luar pengadilan menghasilkan kesepakatan yang bersifat "win-win solution", dijamin kerahasiaan sengketa para pihak, dihindari kelambatan yang diakibatkan karena hal prosedural dan administratif, serta menyelesaikan masalah secara komprehensif dalam kebersamaan dan tetap menjaga hubungan baik. ${ }^{4}$ Seperti pada kasus hukum yang melibatkan bisnis waralaba seperti kasus McDonald's versus Bambang Rachmadi, Perhimpunan Waralaba dan Lisensi Indonesia (Wali) menjadi mediator upaya damai antara Bambang Rachmadi dengan pemegang franchise (waralaba) McDonald's Amerika Serikat. Wali ditunjuk Bambang sebagai mediator untuk menyelesaikan masalah di luar pengadilan,. Wali sudah mengirimkan surat elektronik kepada pemegang waralaba McDonald's Amerika Serikat mengenai niat penyelesaian masalah di luar pengadilan ini dan sudah membalasnya. "Mereka memberi apreasiasi usaha penyelesaian secara mediasi dan kekeluargaan ini, dan akan menindaklanjuti, Proses mediasi, dilanjutkan dengan mempertemukan Bambang Rachmadi dengan pemegang waralaba McDonald's Amerika Serikat.

Berdasarkan uraian di atas, maka penulis tertarik untuk untuk melakukan penelitian mengenai permasalahan tersebut, di mana hasil penelitian ini penulis tuangkan dalam skripsi yang berjudul : "Efisiensi Pemilihan Alternatif Penyelesaian Sengketa dalam Penyelesaian Sengketa Franchise".

Sebagai suatu kontrak bisnis, maka perjanjian waralaba merupakan perjanjian secara tertulis antara Pembeli Waralaba dengan Penerima waralaba. Sebagaimana bisnis pada umumnya, kewajiban-kewajiban dalam suatu kontrak waralaba berpotensi dan terkadang dilanggar atau lalaikan. Timbulnya sengketa dalam bisnis waralaba terjadi bila salah satu pihak melanggar isi perjanjian. Jika salah satu pihak melanggar isi perjanjian, maka pihak yang lain dapat menuntut pihak yang melanggar tersebut sesuai dengan hukum yang berlaku. Apabila telah timbul sengketa, maka para pembisnis waralaba perlu mengambil langkah yang tepat. Alternatif Penyelesaian Sengketa menjadi pilihan bagi para pembisnis waralaba, dikarenakan memiliki kelebihan diantaranya dijamin kerahasiaan sengketa para pihak, dihindari kelambatan yang diakibatkan karena hal prosedural dan administratif, serta menyelesaikan masalah secara komprehensif dalam kebersamaan dan tetap menjaga hubungan baik. Dibandingkan harus membawa masalahnya ke pengadilan dan menghasilkan kesepakatan yang bersifat adversarial yang belum mampu merangkul kepentingan bersama, cenderung menimbulkan masalah baru, dan menimbulkan permusuhan di antara pihak yang bersengketa.

${ }^{4}$ Ibid., p. 5 . 
Permasalahan tersebut oleh penulis akan diteliti dengan mendasarkan pada beberapa pertanyaan. Adapun yang menjadi pertanyaan tersebut adalah sebagai berikut :

1. Apakah faktor yang menyebabkan timbulnya sengketa pada bisnis waralaba?

2. Bagaimanakah efesiensi dari penyelesaian sengketa bisnis waralaba dengan menggunakan lembaga alternatif penyelesaian sengketa ?

Penelitian ini dilakukan dengan tujuan untuk menjawab pertanyaanpertanyaan yang telah dirumuskan dalam pertanyaan penelitian, dengan demikian tujuan penelitian ini adalah untuk mengetahui faktor-faktor yang menyebabkan sengketa pada bisnis waralaba dan untuk dapat mengetahui cara penyelesaian sengketa bisnis waralaba dengan menggunakan lembaga alternatif penyelesaian sengketa.

\section{B. Pembahasan}

Dari segi hukum, franchise melibatkan bidang-bidang hukum perjanjian tentang pemberian lisensi, hukum tentang nama perniagaan, merek, paten, model, dan desain. Bidang-bidang tersebut dapat dikelompokkan dalam bidang hukum perjanjian dan bidang hukum dalam hak intelektual (intellectualproperty right). ${ }^{5} \mathrm{Di}$ dalam hukum kontrak dikenal lima asas penting, yaitu asas kebebasan berkontrak, asas konsensualisme, asas pacta sunt servanda (asas kepastian hukum), asas itikad baik, dan asas kepribadian.

\section{Faktor-faktor yang Menimbulkan Sengketa pada Bisnis Waralaba}

Perkembangan bisnis waralaba yang semakin diminati bagi para pengusaha. Dikarenakan melalui sistem waralaba kegiatan usaha pengusaha kecil Indonesia dapat berkembang secara wajar dengan menggunakan resep, tekonologi, kemasan, manajemen pelayanan, dan merek/jasa pihak lain dengan membayar sejumlah royalti berdasarkan lisensi waralaba. ${ }^{6}$

Menurut Peraturan Pemerintah Republik Indonesia Nomor 42 Tahun 2007 Pasal 1 tentang Waralaba:

"Waralaba yaitu hak khusus yang dimiliki oleh orang perseorangan atau badan usaha terhadap sistem bisnis dengan ciri khas usaha dalam rangka memasarkan barang dan/atau jasa yang telah terbukti berhasil dan dapat dimanfaatkan dan/atau jasa yang telah terbukti

\footnotetext{
${ }^{5}$ Sumardi, Juajir. (1995). Aspek-aspek Hukum Franchise dan Perusahaan Trans Nasional. Bandung: PT Citra Aditya Bakti, p. 21-22.

${ }^{6}$ Muhammad, Abdulkadir. Op. Cit., p. 555.
} 
berhasil dan dapat dimanfaatkan dan/atau digunakan oleh pihak lain berdasarkan perjanjian franchise.

Perjanjian waralaba (franchise agreement) memuat kumpulan persyaratan, ketentuan dan komitmen yang dibuat dan dikehendaki oleh para Franchisor bagi para Franchisee-nya. Di dalam perjanjian waralaba tercantum ketentuan berkaitan dengan hak dan kewajiban Franchisee dan Franchisor. Ketentuan hukum mengenai waralaba sebagai suatu bentuk perjanjian pada dunia bisnis berpedoman dan tunduk kepada ketentuan yang berlaku bagi halnya suatu perjanjian. Waralaba atau franchise merupakan suatu bentuk perjanjian, yang lainnya memberikan hak dan kewenangan khusus kepada pihak penerima waralaba, yang dapat terwujud dalam bentuk, diantaranya sebagai berikut ${ }^{7}$ :

a. Hak untuk melakukan penjualan atas produk berupa barang dan atau jasa dengan mempergunakan nama dagang atau merk dagang tertentu;

b. Hak untuk melaksanakan kegiatan usaha dengan atau berdasarkan pada suatu format bisnis yang tealah ditentukan oleh pemberi waralaba. Perjanjian waralaba harus disusun dnegan cermat agar kerjasama bisnis yang dijalankan menguntungkan kedua belah pihak seimbang.

Suatu perjanjian franchise umumnya terdiri dari pasal - pasal tentang objek, tempat berbisnis pemberian wilayah oleh franchisor kepada franchisee, sewa gedung pelatihan dengan bantuan teknik franchisor, standar operasional, pertimbangan keuangan, klausula - klausula kerahasiaan, klausula - klausula yang membahas persaingan, pertanggungjawaban periklanan dan strategi pemasaran, penetapan harga dengan pembelian, status badan usaha perusahaan, hak untuk menggunakan nama dan merek dagang, masa berlaku dan kemungkingan pembaharuan/perpanjangan perjanjian, pengakhiran perjanjian, penafsiran terhadap perjanjian, dengan pilihan hukum.

Dua area yang biasanya dicakup dalam perjanjian franchise yang paling banyak menimbulkan masalah hukum yang potensial, yaitu pengawasan mutu dan pemutusan perjanjian franchise. Sebenarnya mudah memahami keinginan fraanchisor dalam mengatasi pengawasan mutu, yaitu hanya dengan memelihara standar mutu dan penampilan yang seragam dapat mempertahankan atau melindungi reputasi franchisor dan meningkatkan kepercayaan publik terhadap produknya. Atas dasar ini, franchisor secara khusus mewajibkan franchisee membeli produk dan persediaan. Franchisor menurut harga yang telah ditetapkan atau dari supplier yang dapat memenuhi spesifikasi yangpasti dan standar seperti ditetapkan oleh franchisor. Memaksa franchisee membeli hanya dari franhisor-nya sendiri

\footnotetext{
${ }^{7}$ Awaluddin, Marissa Vidya. (2013). "Aspek Yuridis Perjanjian Waralaba sebagai Perjanjian Khusus”, e-journal unsrat lex privatum. I(1): 85.
} 
mungkin akan melanggar Undang-Undang Antimonopoli dan Persaingan Usaha Tidak Sehat. ${ }^{8}$

Pemutusan perjanjian franchise juga akan menghadapi perangkap hukum (pitfall) jika tidak hati-hati (unwary) dan bijak memecahkan masalah. Perjanjian franchise biasanya menetapkan jangka waktu franchise, misalnya, sepuluh tahun atau lima tahun dan biasanya memuat ketentuan mengenai perpanjangan setelah jangka waktu berakhir. Sebagai bagian dari isi perjanjian (covenants), dibuat juga syarat-syarat perjanjian, franchisee biasanya setuju terhadap janji untuk tidak bersaing selama jangka waktu tertentu setelah berakhirnya franchise. Syarat-syarat tentang kegagalan, seperti franchisee bangkrut atau menunggak pembayaran royalti bulanan atau semi bulanan ketika jatuh tempo, dapat menjadi alasan pemutusan perjanjian franchise. ' Karena itu, perlu disempurnakan lagi cara penyelesaian dalam perjanjian biasanya franchisor setuju untuk memberi waktu kepada franchisee, misalnya, lima belas hari kerja untuk mengatasi keadaan kegagalan tersebut. Kebanyakan perjanjian memuat ketentuan mengenai pemutusan perjanjian franchise. Ini berarti sengketa merupakan kelanjutan dari konflik. Sebuah konflik akan berubah menjadi sengketa apabila tidak dapat terselesaikan.

Secara garis besar, pada umumnya perjanjian waralaba memuat sebagai berikut ${ }^{10}$ :

a. Hak yang diberikan oleh franchisor pada franchisee. Hak yang diberikan meliputi antara lain penggunaan metode atau resep yang khusus, penggunaan merek dan atau nama dagang, jangka waktu hak tersebut dan perpanjangannya, serta wilayah kegiatan dan hak yang lain sehubungan dengan pembelian kebutuhan operasi bila ada.

b. Kewajiban dari franchisee sebagai imbalan atas hak yang diterima dan kegiatan yang dilakukan oleh franchisor pada saat franchisee memulai usaha, maupun seama menjadi anggota dari sistem waralaba.

c. Hal yang berkaitan dengan kasus penjualan hak franchisee kepada pihak lain. Bila franchisee tidak ingin meneruskan sendiri usaha tersebut dan ingin menjualnya kepada pihak lain, maka suatu tata cara perlu disepakati sebelumnya.

d. Hal yang berkaitan dengan pengakhiran perjanjian kerja sama dari masing-masing pihak.

Hal-hal yang diatur oleh hukum dan peraturan perundang-undangan merupakan das sollen yang harus ditaati oleh para pihak dalam perjanjian waralaba. Jika para pihak mematuhi semua peraturan tersebut, maka tidak

\footnotetext{
${ }^{8}$ Muhammad, Abdulkadir. Op.Cit., p. 566.

${ }^{9}$ Muhammad, Abdulkadir. Op.Cit., p 567.

${ }^{10}$ Sutedi, Adrian. (2008). Hukum Waralaba. Bogor: Ghalia Indonesia, p. 82.
} 
akan muncul masalah dalam pelaksanaan perjanjian waralaba. Akan tetapi, sering juga terjadi das sein yang menyimpang dari das sollen. Penyimpangan ini menilbulkan wanprestasi. Wanprestasi terjadi ketika salah satu pihaktidak melaksanakan kewajiban sebagaimana tertera di dalam perjanjian waralaba. Adanya wanprestasi dapat menimbulkan kerugian bagi salah satu pihak. Terhadap kerugian yang ditimbulkan dalam pelaksanaan perjanjian waralaba ini berlaku perlindungan hukum bagi pihak yang dirugikan, yaitu pihak yang dirugikan berhak menuntut ganti rugi kepada pihak yang menyebabkan kerugian. Kemungkinan pihak yang dirugikan mendapat ganti rugi ini merupakan bentuk perlindungan hukum yang diberikan oleh hukum di Indonesia.

Bentuk-bentuk wanprestasi yang dilakukan oleh para pihak dalam perjanjian waralaba tergantung kepada siapa yang melakukan wanprestasi tersebut. Wanprestasi dari pihak franchisee dapat berbentuk tidak membayar biaya waralaba tepat pada waktunya, melakukan hal-hal yang dilarang dilakukan franchisee, melakukan pelayanan yang tidaksesuai dengan sistem waralaba. Dan lain-lain. Yang memungkinkan sistem waralaba berjalan dengan sebagaimana mestinya, tidak melakukan pembinaan kepada franchisee sesuai dengan perjanjian, tidak mau membantu franchisee dalam kesulitan yang dihadapi ketika melakukan usaha waralabanya, danlain-lain. ${ }^{11}$

Selain itu, bagi franchise risiko yang mungkin ditimbulkan dalam bisnis waralaba ialah ketidakpastian karena ada kemungkinan franchisor tidak menepati janji serta risiko permintaan yang tidak sesuai dengan yang dirancanakan sebelumnya akibat kesalahan strategi. ${ }^{12}$ Tidak dapat cepat beradaptasi dengan bisnis waralaba juga dapat menjadi risiko karena bisa saja menurut pendapat franchisee sudah baik, tetapi menurut pelanggan belum. $^{13}$

Berdasarkan uraian di atas, perjanjian waralaba sebagai suatu hubungan hukum dimana dapat diartikan bahwa hubungan antarsubjek hukum menurut ketentuan hukum memiliki hak dan kewajiban antarsubjek yang harus dipenuhi. Dalam hubungan hukum tidak sedikit terjadi permasalahan dikarenakan para pihak tidak memenuhi hak dan kewajibanyang telah di sepakati dalam suatu perjanjian dan sudah tentu menimbulkan kerugian. Terkait dengan perjanjian waralaba, berdasarkan uraian di atas ada berbagai faktor yang menimbulkan sengketa bagi para pihak. Diantaranya, dapat dilihat dari risiko-risiko yang ditimbulkan, adanya pengawasan yang tidak sesuai dilakukan oleh franchisor terhadap franchise, serta pemutusan perjanjian yang dianggap sangat merugikan franchisee.

\footnotetext{
${ }^{11}$ Sutedi, Adrian. Op. Cit., p. 90-91.

${ }^{12}$ Ibid., p. 138.

${ }^{13}$ Ibid.
} 


\section{Efisiensi Penyelesaian Sengketa Waralaba dengan Alternatif Penyelesaian Sengketa}

Sebagai suatu kontrak bisnis tidak jarang menimbulkan perbedaan kepentingan di antara para pelaku bisnis. Perbedaan kepentingan tersebut dapat mengakibatkan timbulnya sengketa. Terjadinya sengketa waralaba dapat diselesaikan melalui jalur litigasi dan non-litigasi. Bila dicermati, waralaba merupakan suatu kontrak bisnis dimana para terdapat kesepakatan yang tidak boleh untuk diketahui umum. Dengan demikian, proses litigasi merupakan pilihan terakhir dalam menyelesaikan sengketa. Sebelum dilakukan perundingan di antara pihak yang bersengketa, baik secara langsung maupun dengan menunjuk kuasa hukumnya guna menghasilkan kesepakatan bersama yang menguntungkan kedua belah pihak. Jika proses perundingan ini tidak menghasilkan kesepakatan, baru para pihak akan menyerahkan kepada arbitrase atau pengadilan untuk menyelesaikan atau memutuskannya. Khusus penyelesaian sengketa melalui arbitrase masih lebih diminati daripada litigasi, terutama untuk kontrak bisnis dan dagang yang bersifat Internasional. ${ }^{14}$ Pilihan hukum yang dicantumkan dalam perjanjian merupakan bagian dari apa yang disebut klausul penyelesaian perselisihan. Di samping pilihan hukum, yang juga merupakan klausul penyelesaian perselisihan ialah pilihan mengenai forum penyelesaian perselisihan (choice of forum). ${ }^{15}$

Penyeselesaian sengketa biasa dilakukan dengan melalui prosedur ajudikasi, namun demikian dengan mengingat waralaba merupakan suatu kontrak bisnis antara pemberi waralaba (franchisor) dan penerima waralaba (franchisee) yang telah disepakati, sehingga timbul kekhawatiran apabila penyelesaian sengketa melalui proses ajudikasi akan menyebabkan beberapa kesepakatan yang tertuang dalam kontrak waralaba yang seharusnya menjadi rahasia antar pihak akan diketahui umum. Dengan demikian, Alternatif penyelesaian sengketa merupakan suatu hal yang paling efektif dan efisien dalam menyelesaikan sengketa atau konflik kepentingan dan pemenuhan kebutuhan. ${ }^{16}$

Akan tetapi, di negara-negara tertentu proses peradilan dapat lebih cepat. Satu-satunya kelebihan proses nonlitigasi ini adalah sifat kerahasiannya karena proses persidangan dan bahkan hasil keputusannya pun tidak dipublikasikan. Penyelesaian sengketa di luar pengadilan ini umumnya dinamakan dengan Alternative Dispute Resolution (ADR). Dewasa ini cara penyelesaian sengketa melalui peradilan mendapat kritik

\footnotetext{
${ }^{14}$ Usman, Rachmadi. Op. Cit., p. 7.

${ }^{15}$ Sutedi, Adrian. Op. Cit., p. 144.

${ }^{16}$ Usman, Rachmadi. (2013). Pilihan Penyelesaian Sengketa di Luar Pengadilan. Bandung: PT Citra Aditya Bakti, p. 41.
} 
yang cukup tajam, baik dari praktisi maupun teoritis hukum. Peran dan fungsi peradilan dianggap mengalami beban yang terlampaui padat (overloaded). Lamban dan buang waktu (waste of time). Biaya mahal (very expensive) dan kurang tanggap (unresponsive) terhadap kepentingan umum. Atau dianggap terlampau formalistik (formalistic) dan terlampau teknis (technically).

Proses Alternatif penyelesaian sengketa yang lebih fleksibel dibandingkan dengan beracara di pengadilan lebih memiliki kemampuan untuk menghasilkan kesepakatan yang mencerminkan kepentingan dan kebutuhan para pihak. Para pihak yang bersengketa dapat duduk secara bersama-sama, merumuskan jalan keluar untuk dapat menyelesaikan permasalahan yang ada. Jalan keluar yang dipilih merupakan hasil kesepakatan kedua belah pihak yang sedang bersengketa.

Menurut Erman Rajagukguk, masyarakat khususnya kaum bisnis lebih menyukai penyelesaian sengketa di luar pengadilan disebabkan tiga alasan, yaitu Pertama, penyelesaian sengketa di pengadilan adalah terbuka, kaum bisnis lebih menyukai sengketa mereka diselesaikan tertutup, tanpa diketahui oleh publik. Kedua, sebagian masyarakat, khususnya orang bisnis menganggap hakim tidak selalu ahli dalam permasalahan sengketa yang timbul. Ketiga, penyelesaian sengketa di Pengadilan akan mencari pihak mana yang salah dan yang benar, sedangkan putusan penyelesaian sengketa di luar pengadilan akan dicapai melalui kompromi. ${ }^{18}$

Beberapa ahli telah mendefinisikan Alternatif Penyelesaian Sengketa, sebagai contoh Standford M. Altschul berpendapat bahwa Alternatif Penyelesaian Sengketa itu adalah ${ }^{19}$ : A trial of a case before a private tribunal agreed to by the parties so as to save legal costs, avoid publicity, and avoid lengthy trial delays.

Black's Law Dictionary mendefinisikan Alternatif Penyelesaian Sengketa sebagai a procedure for setting a dispute by means other than litigation, such as arbitration or mediation.

Sistem peradilan di beberapa negara besar, tidak mampu mengatasi banyaknya perkara yang diajukan ke pengadilan. Amerika Serikat misalnya, karena banyaknya perkara yang diajukan ke pengadilan mendapat julukan masyarakat litigasi (litigious society). Karena penundaan sidang, buaya perkara tinggi, tekanan mental selama proses perkara berlangsung, membuat para sarjana di sana berusaha mencari alternatif selain dari pengadilan.

17 Ariani, Nevey Varida. (2012). "Alternatif Penyelesaian Sengketa Bisnis di Luar Pengadilan”, Jurnal RechtsVinding Media Pembinaan Hukum Nasional. 1(2): 278.

18 Rajagukguk, Eman. (2001). Arbitrase dalam Putusan Pengadilan. Jakarta: Chandra Pratama, p. 30.

19 Winarta, Frans Hendra. (2011). Hukum Penyelesaian Sengketa Arbitrase Nasional Indonesia dan Internasional, Jakarta: Sinar Grafika, p. 13-14. 
Alternatif lain selain dari proses pengadilan inilah dewasa ini dikenal dengan ADR (Alternative Dispute Resolution). ${ }^{20}$ Sengketa bisnis membutuhkan penyelesaian sengketa yang sederhana, cepat, dan biaya ringan. Oleh karena itu, penyelesaian sengketa melalui proses peradilan yang bertele-tele, biaya mahal dan waktu yang lama, kurang cocok untuk penyelesaian sengketa bisnis.

Kedua bentuk penyelesaian tersebut masing-masing memiliki beberapa perbedaan, antara lain:

a. Aspek waktu

Pada penyelesaian sengketa secara litigasi akan memakan waktu yang relatif lebih lama karena dimulai dari pengajuan gugatan sampai pada dikeluarkannya putusan bisa membutuhkan waktu sampai berbulan-bulan bahkan bertahun-tahun. Sebaliknya, pada penyelesaian sengketa secara nonlitigasi akan membutuhkan waktu yang relatif singkat dibandingkan dengan penyelesaian sengketa secara litigasi dikarenakan adanya batasan waktu maksimal ditetapkan sampai pada pengambilan keputusan.

b. Aspek biaya

Penyelesaian sengketa litigasi yang membutuhkan waktu relatif lama akan berdampak langsung pada biaya yang relatif besar yang harus dikeluarkan jika menggunakan penyelesaian sengketa ini. Sebaliknya pada penyelesaian sengketa secara nonlitigasi tentu akan membutuhkan biaya yang relatif lebih kecil dibandingkan dengan penyelesaian sengketa secara litigasi.

Pasal 1 Angka (10) Undang-Undang Nomor 30 Tahun 1999 tentang Arbitrase dan Alternatif Penyelesaian Sengketa (selanjutnya disebut AAPS) mendefinisikan :

"Alternatif penyelesaian sengketa adalah lembaga penyelesaian sengketa atau beda pendapat melalui prosedur yang disepakati para pihak, yakni penyelesaian di luar pengadilan dengan cara konsultasi, negosiasi, mediasi, konsiliasi, atau penilaian ahli”.

Tidak semua sengketa meskipun memenuhi syarat untuk penggunaan Alternatif Penyelesaian Sengketa, harus selalu diselesaikan melalui mekanisme Alternatif Penyelesaian Sengketa. Untuk menjamin kesuksesan pelaksanaan mekanisme Alternatif Penyelesaian Sengketa, prasyarat yang berupa faktor-faktor kunci kesuksesan (key success factors) harus diketahui. Faktor-faktor kunci kesuksesan (key success factors) tersebut antara lain adalah sebagai berikut ${ }^{21}$ :

\footnotetext{
${ }^{20}$ Amriani, Nurmaningsih (2011). Mediasi Alternatif Penyelesaian Sengketa Perdata di Pengadilan, Jakarta: Rajawali Pers, p. 39-40.

${ }^{21}$ Winarta, Frans Hendra. Op. Cit., p. 31-33.
} 


\section{a. Sengketa Masih dalam Batas "Wajar"}

Alternatif Penyelesaian Sengketa kan efektif jika sengketa yang terjadi antara para pihak masih berada dalam keadaan yang 'wajar'. Tingkat sengketa yang berada di atas ambang 'wajar' tersebut akan sulit untuk diselesaikan dengan metode Alternatif Penyelesaian Sengketa.

\section{b. Komitmen Para Pihak}

Keberhasilan penyelesaian sengketa melalui Alternatif Penyelesaian Sengketa ditentukan oleh tekad maupun itikad baik (te goede trouw) para pihak yang bersengketa untuk menerima tanggung jawab atas keputusan mereka sendiri serta menerima legitimasi dari Alternatif Penyelesaian Sengketa. Respon positif terhadap penyelesaian melalui Alternatif Penyelesaian Sengketa ditentukan dari seberapa besar komitmen dan penerimaan atas proses Alternatif Penyelesaian Sengketa dari para pihak yang bersengketa.

\section{c. Keberlanjutan Hubungan}

Penyelesaian melalui Alternatif Penyelesaian Sengketa didasari oleh semangat win-win solution. Oleh karena itu, dengan mempertimbangkan kepentingan di masa depan, maka dari para pihak yang bersengketa harus ada keinginan untuk mempertahankan hubungan baik mereka.

\section{d. Keseimbangan Posisi Tawar Menawar}

Dalam proses penyelesaian sengketa dengan menggunakan Alternatif Penyelesaian Sengketa, terkadang sulit dijumpai keseimbangan dalam posisi tawar-menawar. Namun demikian, apabila para pihak dapat mewujudkan suatu posisi tawar-menawar yang seimbang, maka Alternatif Penyelesaian Sengketa akan menjadi sangat efektif dalam mencapai suatu kesepakatan. Hal ini dikarenakan di antara para pihak akan muncul suatu sikap saling menghargai atas penawaran dan counter penawaran yang terjadi.

\section{e. Proses Bersifat Pribadi dan Hasilnya Rahasia}

Proses dan hasil penyelesaian sengketa melalui Alternatif Penyelesaian Sengketa dilakukan secara tertutup. Hal ini berbeda dengan proses dan hasil penyelesaian sengketa yang dilakukan melalui jalur litigasi yang bersifat terbuka. Hasil penyelesaian sengketa melalui Alternatif Penyelesaian Sengketa tidak dipublikasikan kepada khalayak umum karena dinilai rahasia/confidential, sehingga para pihak dapat fokus pada upaya penyelesaian untuk mendapatkan hasil yang memuaskan dengan semangat win-win solution. 
Alternatif penyelesaian sengketa yang dikenal di Indonesia pada saat ini sebagai berikut :

\section{1) Negosiasi}

Berkenaan dengan pengertian negosiasi sebagaimana disebutkan di atas, ketentuan Pasal 6 ayat (2) UUAAPS menyatakan :

"Penyelesaian sengketa atau beda pendapat melalui aternatif penyelesaian sengketa sebagaimana dimaksud dalam ayat (1) diselesaikan dalam pertemuan langsung oleh para pihak dalam waktu paling ama 14 (empat belas) hari dan hasilnya dituangkan dalam suatu kesepakatan tertulis."

Kata "Pertemuan langsung" sebagaimana tersebut dalam ketentuan Pasal 6 ayat (1) UUAAPS menunjukkan bahwa penyelesaian sengketa atau beda pendapat dilakukan melalui negosiasi. Dengan demikian, dapat disimpulkan bahwa negosiasi itu adalah cara penyelesaian sengketa di luar pengadilan yang dilakukan oleh pihak-pihak yang bersengketa atau kuasanya secara langsung, tanpa keterlibatan pihak ketiga sebagai penengah. Para pihak yang bersengketa yang secara langsung melakukan perundingan atau tawar-menawar sehingga menghasikan suatu kesepakatan bersama.

Pada dasarnya terdapat beberapa teknik negosiasi yang sering digunakan dalam penyelesaian sengketa melalui negosiasi, yaitu ${ }^{22}$ :

a) Teknik negosiasi kompetitif;

b) Teknik negosiasi kooperatif;

c) Teknik negosiasi yang bertumpu pada posisi (positional based);

d) Teknik negosiasi yang bertumpu pada kepentingan (interest base);

e) Teknik Negosiasi yang bersifat lunak (soft); dan

f) Teknik negosiasi yang bersifat keras (hard).

2) Mediasi

Mediasi merupakan salah satu bentuk dari alternatif penyelesaian sengketa di luar Pengadilan. Mediasi mengantarkan para pihak pada perwujudan mengingat penyelesaian sengketa melalui mediasi menempatkan kedua belah pihak pada posisi yang sama, tidak ada pihak yang dimenangkan atau pihak yang dikalahkan (win-win solution).

Pengaturan mengenai mediasi dapat ditemukan dalam ketentuan Pasal 6 ayat (3), ayat (4) dan ayat (5) UU No. 30 Tahun 1999 , Ketentuan mengenai mediasi yang diatur dalam Pasal 6 ayat (3) UU No. 30 Tahun 1999 adalah merupakan suatu proses kegiatan sebagai kelanjutan dari gagalnya negosiasi yang dilakukan oleh para pihak menurut ketentuan Pasal 6 ayat (2)

\footnotetext{
${ }^{22}$ Winarta, Frans Hendra. Op.Cit., p. 72.
} 
UU No. 30 Tahun 1999. Menurut rumusan dari Pasal 6 ayat (3) Undangundang No. 30 Tahun 1999 tersebut dikatakan bahwa atas kesepakatan tertulis para pihak sengketa atau beda pendapat diselesaikan melalui bantuan seorang atau lebih penasihat ahli maupun melalui seorang mediator. Undang- undang tidak memberikan rumusan definisi atau pengertian yang jelas dari mediasi maupun mediator.

Mediasi adalah cara penyelesaian sengketa di luar pengadilan melalui perundingan yang melibatkan pihak ketiga yang bersikap netral (nonintervensi) dan tidak berpihak (impartial) kepada pihak-pihak yang bersengketa serta diterima kehadirannya oeh pihak-pihak yang bersengketa. Pihak ketiga tersebut dinamakan "mediator" atau "penengah", yang tugasnya hanya membantu pihak-pihak yang bersengketa dalam menyelesaikan masalahnya dan tidak mempunyai kewenangan untuk mengambil keputusan. Dengan perkataan lain, mediator di sini hanya bertindak sebagai fasilitator belaka. Dengan mediasi diharapkan dicapai titik temu penyeesaian masalah atau sengketa yang dihadapi para pihak yang bersengketa dan selanjutnya akan dituangkan sebagai kesepakatan bersama. Pengambian keputusan tidak berasa di tangan mediator, tetapi di tangan para pihak yang bersengketa. Mediasi sifatnya tidak formal, sukarea, melihat ke depan, kooperatif, dan berdasar kepentingan. ${ }^{23}$

\section{3) Konsiliasi}

Konsiliasi berasal dari bahasa Inggris, yaitu "conciliation" yang berarti "pemufakatan". ${ }^{24}$ Sementara itu, dalam Kamus Hukum : Dictionary of aw Complete Edition, konsiliasi diartikan sebagai ${ }^{25}$ : Usaha untuk mempertemukan keinginan pihak-pihak yang bersengketa agar mencapai kesepakatan guna menyelesaikan sengketa dengan cara kekeluargaan."

Konsiliasi merupakan suatu penyeesaian sengketa di uar pengadian melalui pemufakatan atau musyawarah yang diakukan sendiri oleh para pihak yang bersengketa dengan didampingi/ditengahi oeh seorang atau lebih pihak yang netral dan bersifat aktif sebagai konsiliator. Mengenai proses penyelesaian sengketa dalam konsiliasi ini sepenuhnya diserahkan kepada para pihak yang bersengketa. Konsiliator di sini bertindak lebih aktif dibandingkan mediator dalam melakukan konsiliasi dan berkewajiban memberikan anjuran kepada pihak-pihak yang bersengketa untuk menyelesaikan atau mengakhiri persengketaan atau perselisihan.

\footnotetext{
${ }^{23}$ Usman, Rachmadi. Op.Cit., p. 99.

${ }^{24}$ Sutiyoso, Bambang. (2006). Penyelesaian Sengketa Bisnis: Solusi dan Antisipasi bagi Peminat Bisnis dalam menghadapi Sengketa kini dan mendatang. Yogyakarta: Citra Media Hukum, p. 92.

${ }^{25}$ Marwan M. dan P. Jimmy. (2009). Kamus Hukum: Dictionary of Law Complete Edition. Surabaya: Reality Publisher, p. 376.
} 
Tujuan dari pertemuan konsiiasi adalah untuk membawa pihak yang berkepentingan untuk bersama-sama mencari jalan keluar dalam menyelesaikan perselisihan. Pada dasarnya konsiliasi memiliki karakteristik yang hampir sama dengan mediasi, hanya saja peran konsiliator lebih aktif dibandingkan mediator yaitu ${ }^{26}$ :

a) Konsiliasi adalah proses penyelesaian sengketa di luar pengadilan secara kooperatif.

b) Konsiliator adalah pihak ketiga yang netral yang terlibat dan diterima oleh para pihak yang bersengketa di dalam perundingan.

c) Konsiliator bertugas membantu para pihak yang bersengketa untuk mencapai penyelesaian.

d) Konsiliator bersifat aktif dan mempunyai kewenangan mengusulkan pendapat dan merancang syarat-syarat kesepakatan di antara para pihak.

e) Konsiliator tidak mempunyai kewenangan membuat keputusan selama perundingan berlangsung.

f) Konsiliasi bertujuan untuk mencapai atau menghasilkan kesepakatan yang dapat diterima pihak-pihak yang bersengketa guna mengakhiri sengketa.

4) Arbitrase

Perkataan arbitrase berasal dari arbitrare (bahasa Latin) yang b?erarti kekuasaan untuk menyelesaikan sesuatu menurut kebijaksanaan. ${ }^{27}$ Frank Elkoury dan Edna Elkoury dalam bukunya How Arbitration Works mengartikan $^{28}$ :

"Arbitration adalah suatu proses yang mudah atau simple yang dipilih oleh para pihak secara sukarela yang ingin agar perkaranya diputus oleh juru pisah yang netral sesuai dengan pilihan mereka di mana keputusan mereka berdasarkan dalil-dalil dalam perkara tersebut. Para pihak setuju sejak semula untuk menerima putusan tersebut secara final dan mengikat."

Pasal 1 butir (1) UU Nomor 30 Tahun 1999 tentang Arbitrase dan Alternatif Penyelesaian Sengketa yang dimaksud dengan arbitrase adalah : "Penyelesaian sengketa perdata di luar peradilan umum yang didasarkan pada perjanjian arbitrase yang dibuat secara tertulis oleh para pihak yang bersengketa."

Arbitrase pada dasarnya adalah menghindari pengadilan sebab dibandingkan dengan ajudikasi publik, arbitrase lebih memberikan kebebasan, pilihan, otonomi dan kerahasiaan kepada para pihak yang

\footnotetext{
${ }^{26}$ Sutiyoso, Bambang. Op.Cit., p. 5-6.

${ }^{27}$ Frans Hendra Winata, Op.Cit., p. 36.

${ }^{28}$ Subekti, R. (1992). Arbitrase Perdagangan. Bandung: Binacipta, p. 2.
} 
bersengketa. Dalam arbitrase ini para pihak dapat memilih hakim yang dikehendaki, sehingga dapat menjamin kenetralan dan keahlian sesuai dengan persengketaan mereka. Para pihak dapat memilih hokum yang dikehendaki untuk dipakai dasar penyelesaian sengketa. Biaya lebih murah dan cenderung lebih informal. Berdasarkan batasan tersebut, dapat diartikan arbitrase sebagai salah satu cara penyelesaian sengketa di luar peradilan umum (nonlitigasi) yang bentuknya berupa perjanjian tertulis dari para pihak yang bersengketa, dimana proses penyelesaiannya melibatkan pihak ketiga yaitu arbiter atau majelis arbiter sebagai pemutus sengketa yang terjadi guna mencapai win-win solution bagi para pihak.

Penyelesaian sengketa melalui arbitrase dapat dilakukan oleh lembaga-lembaga yang berwenang menangani sengketa diantaranya:

a) Badan Arbitrase Nasional Indonesia (BANI)

b) Badan Arbitrase Pasar Modal Indonesia (BAPMI)

c) Badan Arbitrase Syariah Nasional (BASYARNAS)

d) Badan Arbitrase dan Mediasi Hak Kekayaan Intelektual (BAM HKI)

e) Badan Arbitrase Perdagangan Berjangka Komoditi (BAKTI)

f) Badan Penyelesaian Sengketa Konsumen (BPSK)

Mengenai objek sengketa yang dapat diselesaikan melalui arbitrase telah diatur daam ketentuan Pasal 5 UUAAPS. Ini berarti, tidak semua objek sengketa di bidang perdata dapat diselesaikan mealui arbitrase, hanya bidang perdata tertentu yang telah ditentukan dalam UUAAPS. Menurut ketentuan dalam Pasal 5 ayat (1) UUAAPS bahwa :

"Sengketa yang dapat diselesaikan melalui arbitrase hanya sengketa di bidang perdagangan dan mengenai hak yang menurut hukum dan peraturan perundang-undangan dikuasai sepenuhnya oleh pihak yang bersengketa."

Penjelasannya tidak memberikan penjelasan yang termasuk dalam "bidang perdagangan" tersebut sebagaimana yang disebutkan dalam ketentuan ini dihubungkan dengan Penjelasan atas Pasal 66 UUAAPS, kita akan dapat mengetahui "ruang lingkup perdagangan", tersebut, yaitu kegiatan-kegiatan, antara lain, di bidang :

a) Perniagaan

b) Perbankan

c) Keuangan

d) Penanaman Modal

e) Industri, dan

f) Hak Kekayaan Intelektual.

Dari ketentuan Pasal 5 ayat (1) UUAAPS tersebut dihubungkan dengan Penjelasan atas Pasal 66 UUAAPS, maka objek sengketa yang dapat 
diselesaikan melalui arbitrase diberikan pengertian yang luas, asalkan objek sengketa tersebut termasuk dalam ruang lingkup "hukum perdagangan". 29

\section{Penutup}

Pada suatu sengketa bisnis para pihak lebih banyak memilih untuk menghindari untuk menyelesaiakan sengketanya melalui pengadilan. Dikarenakan ada banyak faktor yang dipertimbangkan oleh para pembisnis tersebut. Kendala yang timbul dengan menyelesaikan sengketa di pengadilan adalah soal waktu yang lama yang sudah tentu berakibat pada biaya yang harus dikeluarkan. Selain itu, pada suatu kontrak bisnis waralaba terdapat suatu kerahasiaan yang menjadi kunci dari usahanya tersebut. Apabila sengketa bisnis diselesaian melalui pengadilan, risiko publikasi kerahasiaan tersebut tidak dapaty dihindarkan oleh pembisnis. Maka dari itu, pembisnis lebih banyak memilih alternatif penyelesaian sengketa di luar pengadilan untuk menyelesaikan sengketa bisnis. Dikarenakan, selain dianggap lebih efisien penyelesaian sengketa dengan alternatif penyelesaian sengekta akan dapat menghasilkan suatu "win-win solution" bagi para pihak. Sehingga apabila telah terjadi kesepakatan dari perundingan para pihak maka tidak ada yang terlalu merasa dirugikan dikarenakan telah ada "win-win solution" yang disepakati sehingga para-para pihak akan dapat bernegosiasi terhadap keinginan mereka untuk menyelesaikan sengketa bisnis. Selain itu, kerahasiaan yang mereka miliki tidak akan terpublikasi seperti yang terjadi pada penyelesaian sengketa melalui pengadilan. Sehingga, alternatif penyelesaian sengketa dianggap lebih efisien untuk menyelesaikan sengketa bisnis waralaba.

\section{Daftar Pustaka}

\section{A. Buku}

Marwan, M. (2009). Kamus Hukum: Dictionary of Law Complete Edition. Surabaya: Reality Publisher.

Muhammad, Abdulkadir. (2004). Hukum dan Penelitian Hukum. Bandung: PT Citra Aditya Bakti.

PT Citra Aditya Bakti.

(2010). Hukum Perusahaan Indonesia. Bandung:

Rajagukguk, Eman. (2001). Arbitrase dalam Putusan Pengadilan. Jakarta: Chandra Pratama.

Subekti, R. (1992). Arbitrase Perdagangan. Bandung: Bina Cipta.

\footnotetext{
${ }^{29}$ Usman, Rachmadi. Op.Cit., p. 161.
} 
Sumardi, Juajir. (1995). Aspek-aspek Hukum Franchise dan Perusahaan Trans Nasional. Bandung: PT Citra Aditya Bakti.

Sutedi, Adrian. (2008). Hukum Waralaba. Bogor: Ghalia Indonesia.

Sutiyoso, Bambang. (2006). Penyelesaian Sengketa Bisnis: Solusi dan Antisipasi bagi Peminat Bisnis dalam menghadapi Sengketa kini dan mendatang. Yogyakarta: Citra Media Hukum.

Usman, Rachmadi. (2013). Pilihan Penyelesaian Sengketa di Luar Pengadilan. Bandung: PT Citra Aditya Bakti.

Winata, Frans Hendra. (2011). Hukum Penyelesaian Sengketa Arbitrase Nasional Indonesia dan Internasional. Jakarta: Sinar Grafika.

\section{B. Jurnal}

Ariani, Nevey Varida. (2012). "Alternatif Penyelesaian Sengketa Bisnis di Luar Pengadilan”, Jurnal RechtsVinding Media Pembinaan Hukum Nasional, 1(2): 278.

Marissa Vidya Awaluddin, (2013). “Aspek Yuridis Perjanjian Waralaba sebagai Perjanjian Khusus", e-journal unsrat lex privatum I(1): 85.

\section{Peraturan Perundang-Undangan}

Kitab Undang-Undang Hukum Perdata.

Undang-Undang Nomor 30 Tahun 1999 tentang Arbitrase dan Alternatif Penyelesaian Sengketa.

Peraturan Pemerintah Republik Indonesia Nomor 42 Tahun 2007 tentang Waralaba.

Peraturan Menteri Republik Indonesia Nomor 12/M-Dag/Per/3/2006 tentang Ketentuan dan Tata Cara Penerbitan Surat Tanda Pendaftaran Usaha Waralaba.

Peraturan Menteri Perindustrian danPerdagangan RI Nomor 31/MDAG/PER/8/2008 tentang Penyelenggaraan Waralaba. 